\title{
Мелосский диалог
}

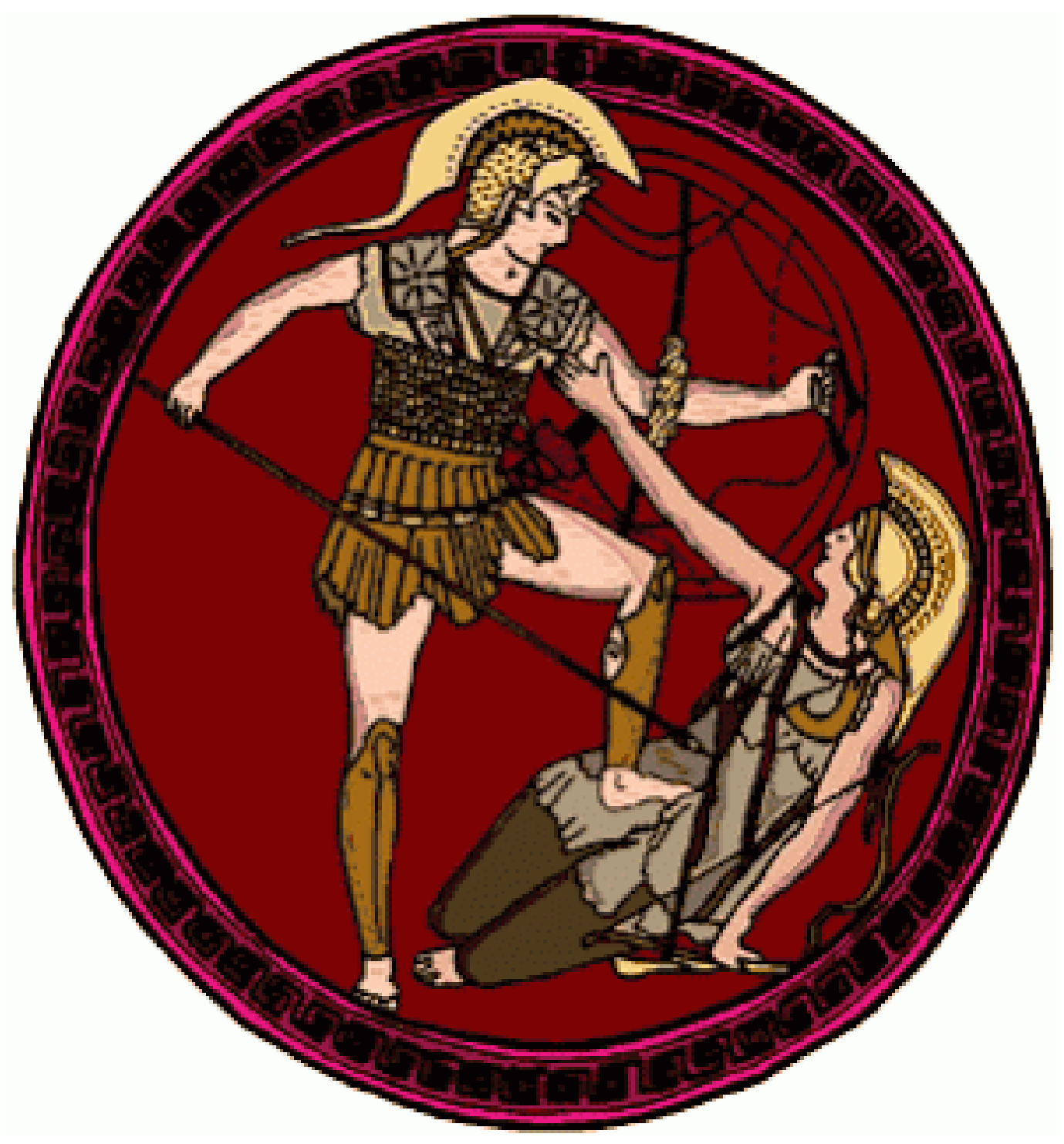

\author{
Отрывок из \\ «Истории Пелопоннесской \\ войны» Фукидида
}


Затем афиняне выступили в поход на остров Мелос с эскадрой в составе 30 своих кораблей, 6 хиосских и 2 лесбосских, имея на борту 1200 гоплитов, 300 лучников, 20 конных стрелков из самих Афин и еще около 1500 воинов от союзников и островитян. Мелос - лакедомонская колония, и жители ее не желали подчиняться афинянам подобно другим островитянам. Сначала мелосцы пытались оставаться нейтральными. Затем, когда афиняне стали принуждать их подчиниться, опустошая остров, дело дошло до открытой войны. Итак, стратеги Клеомед, сын Ликомеда, и Тисий6, сын Гисимаха, расположились на острове лагерем с упомянутыми силами. Однако до начала враждебных действий они отправили послов, чтобы договориться с мелосцами. Мелосцы же не допустили послов в народное собрание, но предложили изложить свое поручение в кругу властей и нескольких знатнейших граждан.

Афинские послы сказали следующее: «Наши переговоры ведутся не в народном собрании, очевидно, с той целью, чтобы мы сразу не ввели в обман ваших людей, если бы смогли развернуть перед ними в одной связной речи соблазнительные и неопровержимые доводы. Мы ведь понимаем, что ради этого вы и привели нас в этот тесный круг. Оградите же себя от этого соблазна еще вернее, вы, заседающие здесь; судите не по одной речи: вы можете прерывать нас и возражать по каждому отдельному пункту в случае несогласия с ним. И прежде всего скажите, согласны ли вы с нашим предложением?»

Мелосские синедры отвечали: «Мы не возражаем против вашего благожелательного предложения спокойно обсудить дело. Однако ваши военные приготовления (а не только намерения) явно противоречат вашим словам. Ведь мы видим, что вы пришли сюда как судьи с притязанием на окончательное решение в предстоящих переговорах. И, по всей вероятности, если мы при этом останемся правы, а потому не уступим, то будет война; если же согласимся, то нас ожидает рабство».

А ф и н я н е. Конечно, если вы пришли, чтобы строить догадки о будущемили с какой-либо иной целью, а не для того, чтобы обсуждать меры для спасения вашего города, мы можем кончить переговоры. Если же вы пришли для такого обсуждения, то мы можем к нему приступить.

М е л о с ц ы. Людям в нашем положении естественно и простительно много говорить и высказывать различные мнения. И притом, это собрание созвано для нашего спасения. Поэтому пусть обсуждение, если вам угодно, идет, как предлагаете вы. 
А ф и н я н е. Очень хорошо. Однако мы и сами не будем прибегать к красивым, но неубедительным словам, распространяясь о том, что наше право на владычество приобретено победой над Мидянином или что мы пришли наказать вас за причиненную обиду, и вас просим - не думайте убедить нас тем, что вы, будучи колонией лакедемонян, не участвовали в их походах, или тем, что никогда не чинили нам обид: добивайтесь только того, что и вы и мы по здравому рассуждению одинаково считаем возможным. Ведь вам, как и нам, хорошо известно, что в человеческих взаимоотношениях право имеет смысл только тогда, когда при равенстве сил обе стороны признают общую для той и другой стороны необходимость. В противном случае более сильный требует возможного, а слабый вынужден подчиниться.

М е л о с ц ы. Как нам, по крайней мере, кажется, полезно - раз уж вы решили, устранив вопрос о праве, говорить только о пользе, - чтобы вы не отменяли понятие общего блага; чтобы с каждым человеком, находящимся в опасности, поступали по пристойной справедливости и чтобы получил какую-то помощь и тот, чья правота не доказана с полной очевидностью. И это так же в ваших интересах, как и в наших, тем более что в случае падения вы подадите другим пример жестокого возмездия.

А ф и н я н е. Мы не падаем духом при мысли, что может наступить конец нашему владычеству. Ведь не те, кто господствует над другими, как лакедемоняне, страшнее всего побежденным (да и не с лакедемонянами теперь у нас идет борьба), но гораздо опаснее подчиненные, если они восстанут против своих властителей и победят их. Но заботу об этом вы уж предоставьте нам. Мы постараемся показать вам, что пришли ради пользы нашего владычества, и будем говорить с вами теперь о спасении вашего города. Ведь мы не желаем такого господства над вами, которое было бы для вас тягостно; напротив, мы хотим вашего спасения к обоюдной выгоде.

М е л о с ц ы. Но как же рабство может быть нам столь же полезно, как вам владычество?

А ф и н я н е. Потому что вам будет выгоднее стать подвластными нам, нежели претерпеть жесточайшие бедствия. Наша же выгода в том1, чтобы не нужно было вас уничтожить.

М е л о с ц ы. Но не согласитесь ли вы оставить нас нейтральными, не врагами вам, а друзьями, с условием не вступать ни в один из союзов? 
А ф и н я н е. Ваша неприязнь вредит нам не столь сильно: ваша дружба в глазах подвластных нам будет признаком нашей слабости, а вражда ваша доказательством мощи.

М е л о с ц ы. Неужели подвластные вам считают правильным не делать различия в отношении к городам, вовсе независимым от вас, и теми вашими колониями, которые после восстания вновь подчинены вами?

А ф и н я н е. По мнению наших подданных, ни утех, ни у других нет недостатка в возражениях. Все же они понимают, что независимые города сохраняют свободу потому лишь, что в состоянии защищаться, и мы не нападаем на них из страха. Поэтому ваше подчинение, помимо расширения нашего господства, усилит нашу безопасность. Тем более что мы господствуем на море, и вы как островитяне, будучи слабее других островитян, должны нам подчиниться.

М ел о с ц ы. А разве наше предложение не может обеспечить вам безопасности? Но так как вы, отклонив наши соображения, основанные на требованиях справедливости, убеждаете нас подчиниться требованиям вашей выгоды, то и мы также попытаемся объяснить вам нашу выгоду, убедить вас в том, что она совпадает с вашей. Неужели вы хотите все нейтральные города сделать своими врагами? Ведь, увидев нашу участь, они поймут, что когда-нибудь придет и их черед. Разве этим вы еще больше не усилите ваших нынешних врагов и не заставите против воли стать вашими врагами тех, кто и не помышлял об этом?

А ф и н я н е. Нам вовсе не так опасны какие-то материковые города, которые еще долго будут медлить с мероприятиями для защиты своей свободы. Мы опасаемся скорее независимых островитян вроде вас и всех, которые уже раздражены необходимостью подчиниться нам. Ведь эти еще не покоренные города, дав волю своему безрассудству, скорее всего подвергнут и самих себя, и нас явной опасности.

М е л о с ц ы. Действительно, если и вы идете на столь великую опасность, чтобы сохранить свое господство, и уже порабощенные города-чтобы освободиться от него, то для нас, еще свободных, было бы величайшей низостью и трусостьюне испробовать все средства спасения, прежде чем стать рабами.

А ф и н я н е. Вовсе нет, если только вы здраво рассудите. Ведь вы не состязаетесь в доблести с равным противником, которому уступить зазорно, а ищете спасения, встретив противника, которому вы не в силах противостоять. 
М е л о с ц ы. Как известно, военное счастье иной раз благоприятствует даже более слабому и разница в силах обоих противников не дает безусловного перевеса одному из них. Если мы тотчас уступим вам, то лишаемся всякой надежды; если же будем действовать, то у нас останется хоть надежда выстоять.

А ф и н я н е. Надежда, утешение во всякой опасности если и повредит человеку, располагающему избытком средств, то не погубит его окончательно. Но тот, кто ставит на карту все свое состояние (ведь надежда по природе расточительна), лишь в самый момент своего полного крушения, когда уже поздно остерегаться, видит всю ее обманчивость. Вы - бессильны, и ваше существование на волоске. Не подвергайте же себя такой опасности, не повторяйте ошибок большинства людей, которые в беде или во время недуга, когда спасение еще не превышает человеческих возможностей, пренебрегши действительными надеждами, обращаются к призрачным и прибегают к предсказаниям, оракулам и подобным обманным средствам, которые верящим в них несут гибель.

М е л о с ц ы. Будьте уверены, мы хорошо знаем, как трудно бороться против вашего могущества и счастья (если оно и тут даст вам преимущества). Однако мы все же верим, что божество нас не умалит, ибо мы благочестиво противостоим вам, поступающим неправедно. Недостаток военных сил нам возместит союз с лакедемонянами, которые, хотя бы ради племенного родства и из чувства чести, должны оказать нам помощь. Поэтому-то наша решимость сопротивляться не так уже неразумна.

А ф и н я н е. Благость богов, надеемся, не оставит и нас, ибо мы не оправдываем и не делаем ничего противоречащего человеческой вере в божество или в то, что люди между собой признают справедливым. Ведь о богах мы предполагаем, о людях же из опыта знаем, что они по природной необходимости властвуют там, где имеют для этого силу. Этот закон не нами установлен, и не мы первыми его применили. Мы лишь его унаследовали и сохраним на все времена. Мы уверены также, что и вы (как и весь род людской), будь вы столь же сильны, как и мы, несомненно, стали бы так же действовать. Итак, со стороны божества у вас, полагаем, нет оснований опасаться поражения. Что же до лакедемонян, то если вы воображаете, что они чести ради помогут вам, то мы преклоняемся перед вашим прекраснодушием, но не завидуем вашему неразумию. Лакедемоняне сами по себе в большинстве своих внутренних установлений проявляют много доблести. О внешней же их политике многое можно было бы сказать, но лучше, пожалуй, обобщая, охарактеризовать ее так: среди всех известных нам людей они с наибольшей откровенностью отождествляют приятное для них - с честным, a 
выгодное - со справедливым. А при таком образе их мыслей видеть в них вашу надежду на спасение в нынешних условиях неосновательно.

М е л о с ц ы. Однако именно этот их образ мыслей и позволяет нам верить, что они, соблюдая свою выгоду, не захотят предать мелосцев, своих колонистов, утрачивая доверие своих друзей в Элладе и потворствуя своим врагам.

А ф и н я н е. Но разве вы не думаете, что выгода зависит от безопасности, а справедливая и честная политика приносит только опасность? На эту политику лакедемоняне большей частью и не осмеливаются.

М е л о с ц ы. Все же думается, что ради нас они будут готовы скорее, чем ради других, подвергнуться риску и сочтут его в этом случае меньшим. Ведь мы находимся вблизи от театра военных действий1 в Пелопоннесе, и лакедемоняне могут скорее положиться на нашу преданность им, так как мы - их соплеменники.

А ф и н я н е. Тот, кого призывают на помощь на войне, находит опору не в доброжелательстве ищущего помощи, но в превосходстве его военной мощи. И лакедемоняне придают этому больше значения, чем другие: они так мало доверяют собственным военным силам, что нападают на соседей только вместе с многочисленными союзниками. Поэтому маловероятно, чтобы при нашем господстве на море они переправились на ваш остров.

М е л о с ц ы. Но они ведь могут послать нам и союзников. Ведь Критское море велико, и поэтому господствующему на нем флоту труднее захватить противника, чем последнему скрыться от него. Если же лакедемонянам не удастся помочь нам на море, они могут напасть на вашу землю и на ваших союзников (еще оставшихся у вас после похода Брасида). Тогда вам придется воевать уже не за чужую страну, но за союзную область и вашу собственную землю.

А ф и н я н е. Если действительно случится что-либо подобное, то для нас это не будет неожиданностью, да и вам по опыту известно, что афиняне еще никогда не снимали осады из страха перед врагом в другом месте. Мы замечаем, однако, что несмотря на то, что вы, по вашим словам, желаете договориться о спасении вашего города, вы в этой долгой беседе вовсе не упомянули о средствах спасения, на которые люди обычно рассчитывают. Ваша крепчайшая опора - это надежда на будущее. Ваши собственные силы слишком слабы в сравнении с противостоящей вам теперь мощью, которую вам не одолеть. Поэтому с вашей стороны было бы весьма неразумно, отсылая нас, не принять более здравого 
решения. Вы не поддадитесь, конечно, тому ложному чувству чести, которое в явных и несущих позор и опасность положениях чаще всего толкает людей на гибель. Действительно, многие заранее видели, что им предстоит, но так называемое чувство чести соблазнительной силой этого слова довело их до того, что они, склонившись перед ним, попадали в непоправимые беды, а затем прибавляли к ним еще больший позор, скорее из-за своего постыдного безрассудства, чем в силу неблагоприятных обстоятельств. Итак, будьте же благоразумны и остерегайтесь этого. Не думайте, что противоречит нашей чести отказ от сопротивления великой державе, которая выставляет умеренные требования, заключающиеся в том, чтобы вы присоединились к союзу с нею (с уплатой дани), сохраняя владение своей землей. Если вам предлагают выбор: война или безопасность- не настаивайте из упрямства на худшем. Ведь те, кто не уступает равным себе, с могущественными ведет себя благоразумно, а со слабыми - умеренно, преуспеют более всего. Итак, после нашего ухода всесторонне обсудите положение и подумайте, что вы решаете судьбу отечества, преуспевание или гибель которого теперь всецело зависит от единого вашего решения.

Затем афиняне покинули собрание. Мелосцы же, оставшись одни, посоветовались между собой и приняли решение в том же смысле, как они высказывались уже раньше во время переговоров с афинянами, и отвечали так:

«Афиняне! Наше мнение и воля неизменны, и мы не желаем в один миг отказываться от свободы в городе, существующем уже 700 лет. Полагаясь на судьбу, до сих пор по божественной воле хранившую нас, и на помощь людей и в их числе лакедемонян, мы попытаемся сохранить нашу свободу. Мы предлагаем вам мир и дружбу, но в войне желаем остаться нейтральными и просим вас покинуть нашу страну, заключив приемлемый для обеих сторон договор».

Таков был ответ мелосцев. Афиняне же, считая, что на этом переговоры закончены, ответили им:

«Итак, если судить по вашим решениям, то вы - единственные люди, для кого будущее достовернее настоящего, которое у вас пред глазами, и вы принимаете незримое за уже осуществляющееся, так как оно вам желательно. Предавшись всецело вере в лакедемонян и в судьбу, вы рискнули всем, но вы все и потеряете!»

Затем афинские послы возвратились в свой лагерь. А так как мелосцы не пошли ни на какие уступки, то афинские военачальники тотчас же открыли военные действия: распределив осадные работы между отдельными городами, они окружили мелосцев осадной стеной. Потом афиняне снова отступили с большой 
частью войска, оставив гарнизон из граждан и союзников. Оставшиеся продолжали осаду города с моря и с суши.

$<\ldots .>$

Афиняне всеми силами энергично принялись за осаду, и к тому же в среде самих осажденных завелась измена.

Поэтому мелосцам пришлось сдаться на милость победителей. Афиняне перебили всех взрослых мужчин и обратили в рабство женщин и детей. Затем они колонизовали остров, отправив туда 500 поселенцев. 